\title{
PENGEMBANGAN PEMURIDAN KONTEKSTUAL BAGI PEMUDA MASA KINI SEBAGAI PEMIMPIN YANG BERKUALITAS
}

\author{
SELMI DATU RANTE MIA \\ JURUSAN KEPEMIMPINAN KRISTEN
}

Email: selmimiadatu@gmail.com

\begin{abstract}
ABTRAK
Dalam pemuridan Kontekstual bahan yang utama adalah Alkitab dan mengajarkan isi Alkitab. Pemuridan adalah suatu proses memuridan dan dimuridan bagi orang Kristen agar menjadi semakin serupa dengan Kristus Allah kita. Pemuridan juga adalah adalah proses yang berlangsung sepanjang hidup kita sebagai orang percaya. Pemuridan adalah suatu proses di mana sesorang belajar sesuatu yang bergun bagi dirinya dan bagi orang lain.
\end{abstract}

\section{PENDAHULUAN}

\section{A. Latar Belakangan}

Pemuridan kontekstual (Kelompok Tumbuh Bersama Kontektual) adalah salah satu bentuk kelompok pertumbuhan rohani yang berdiri dari 3-6 orang yang berkomitmen untuk bertumbuh ke arah kedewasaan penuh dalam Kristus. ${ }^{1}$ Tujuan pemuridan kontekstual ini adalah agar pemuda masa kini dapat bertumbuh sesuai dengan pemahaman Alkitab yang memiliki komitmen lebih mendalami Firman Tuhan dan mengaplikasikannya dalam kehidupan sehari-hari. Bagi pemuda masa kini yang memiliki iman percaya yang masih ombang-ambing yang perlu mempelajari dan mengembangkang pemuridan kontekstual ini agar lebih mengenal Tuhan dan dapat mengatasi tantangan hidup yang dihadapi dengan selalu rendah hati. Pemuda masa kini adalah golongan yang masih muda yang memerlukan pembinaan dan pengembangan ke arah yang lebih baik. Masa mudah di mana sesorang mengalami proses pencarian indentitas diri. ${ }^{2}$ Seringkali kau muda diperhadapkan dengan kejadian-jadian yang menghambat mereka dalam mencari jati diri, gagal dalam

\footnotetext{
1 T. Haryono dan Yuliati, Pemuridan Kontekstual : contextual bible group. (Surakarta, Yayasan Gamaliel, 2018) 60

2 J. S. Badudu dan Sultan Muhammad Zain, Kamus Umum Bahasa Indonesia (Jakarta: Pustaka Sinar Harapan 1994),1028,s.v “Pemuda."
} 
menemukan indentitas diri yang sebenarnya. Banyak pemuda masa kini yang tidak punya gairan dan semangat untuk memuji Tuhan di dalam persekutuan dan ibadah. ${ }^{3}$

\section{B. Rumusan Masalah}

Berdasarkan latar belakang tersebut dapat ditarik suatu rumusan masalah penelitian yaitu: Bagaimana pengembangan pemuridan kontekstual bagi pemuda masa kini sebagai pemimpin yang berkualitas?

\section{Tujuan dan Manfaat}

Tujuan dari penelitian ini adalah untuk mengetahui pemgembangan pemuridan kontekstual bagi pemuda di masa kini sebagai pemimpin yang berkulitas dalam pengajaran Kristus.

Manfaat yang diperoleh dari hasil penelitian ini adalah pertama mengembangkan pemuridan kontekstual bagi pemuda masa kini, kedua dapat mengatasi permasalahan pemuridan kontekstual bagi pemuda masa kini, ketiga menolong bagi pemuda masa kini untuk bertumbuh dalam imannya dan percaya kepada Yesus Kristus.

\section{PEMBAHASAN}

\section{Pemuridan}

Pemuridan menjadi salah satu cara yang dipakai Allah untuk mencetak pemuda masa kini sebagai pemimpin yang berkualitas. Yesus adalah seorang pemimpin pemuridan dimana kita di tuntut mendasari oleh ajaran Yesus Kristus dan kepemimpinan Yesus Kristus. Dalam pemuridan Kontekstual bahan yang utama adalah Alkitab dan mengajarkan isi Alkitab. Pemuridan adalah suatu proses memuridan dan dimuridan bagi orang Kristen agar menjadi semakin serupa dengan Kristus Allah kita. Pemuridan juga adalah adalah proses yang berlangsung sepanjang hidup kita sebagai orang percaya. Pemuridan adalah suatu proses di mana sesorang belajar sesuatu yang bergun bagi dirinya dan bagi orang lain.

\section{Pemuridan Kontekstua}

Pemuridan Kontekstual Manusia adalah mahluk yang diciptakan Allah menurut rupa dan gambar Allah sendiri. 1) Namun ketika manusia itu memilih untuk memberontak terhadap Allah, rupa dan gambar Allah itu menjadi rusak. Kemuliaan Allah yang ada pada

\footnotetext{
${ }^{3}$ Roy B. Zuck dan Warren S. Benson, Pedoman Lengkap Untuk Pelayanan Kaum Mudah Jilid 1 (Bandung: kalam Hidup, 1978), 10 .
} 
manusia itu menjadi hilang. 2) Namun Allah yang penuh kasih mengutus Anak-Nya yang tunggal ke dalam dunia untuk menebus manusia berdosa. 3) Dan setiap orang yang menerimanya sebagai Tuhan dan Juru Selamat pribadi mengalami penulihan identitas diri yang telah rusak karena pemberontakan itu. 4) Pertobatan bukan akhir dari kehidupan rohani seseorang tetapi awal kehidupan rohani yang berorientasi ke depan berupa pembangunan karakter ilahi menuju keserupaan dengan gambar Anak-Nya. 5.) Pengertian Pemuridan diartikan sebuah proses menuntun orang lain untuk menerima Kristus dan menjadikannya pengikut yang setia belajar dari Tuhan.

Pemuridan adalah pelayanan seutuhnya terhadap orang percaya ialah mendidik melalui pembinaan iman, dengan tujuan untuk mendewasakan setiap anggotanya dalam Kristus. Pemuridan juga diartikan dengan hubungan antara guru dan murid, didasarkan pada pola Kristus dan kehidupan-nya yang diajarkan kepada murid- Nya. Dasar Teologis Dasardasar Alkitabiah tentang pemuridan dalam Perjanjian Lama antara lain: pertama, pada waktu istilah murid telah lama dikenal orang. Pertama, secara teoritis, mengetahui hubungan pemuridan kontekstual terhadap spiritualitas pemuda masa kini. Kedua, sebagai masukkan untuk mengembangkan pemuridan kontekstual sehingga bisa lebih baik dan dapat meningkatkan kehidupan spiritualitas pemuda masa kini Kejadian 1: 26-27, Mazmur 8: Kejadian 3-4: 8, Yesaya 53, Roma 3: 23, 6: 3 Yohanes 3: 16, 1 Yohanes 4: Yohanes 1: 12, 2 Korintus 5: 175 Roma 8: Kontekstual Kelompok Tumbuh Bersama Kontekstual adalah sekelompok murid Kristus terdiri dari 3-6 orang yang berkomitmen untuk bertumbuh dewasa serupa Kristus melalui: mempelajari Firman Tuhan, menaati Firman Tuhan yang memiliki relasi yang saling bergantung kepada orang lain. Kelompok Tumbuh Bersama ini disebut KTB Kontekstual karena: konteks anggota sangat diperhatikan baik kebutuhan rohani maupun kevariasian setiap pribadi, pemahaman Alkitab secara induktif dengan metode penafsiran kontekstual, konteks relasi kelompok antara pemimpin dengan anggota bersifat fungsional-inter dependensi (saling kebergantungan), pertumbuhan rohani hanya terjadi dalam konteks tubuh Kristus.

Pemuridan kontektual adalah pemuridan yang menjadi kontektual pertimbangan yang bahan utama yang mempelajari isi Alkitab sebagai orang percaya. Konteks adalah baik konteks Alkitab maupun konteks pemuridannya. Visi dan misi dari KTBK ini adalah supaya mereka serupa dengan Yesus. Yang lebih utama yang penting yaitu;

1) bertumbuh dan kedewasaan penuh dalamYesus Kristus, 
2) melengkapi dengan pemahami Alkitab pemuridan Kontekstual,

3) melaksanakan ketaatan terhadap Firman Tuhan,

4) melipatgandakan KTBK dengan mendelegasi setiap orang menjadi pemimpin KTBK yang baru.

Dengan tercapainya visi dan misi maka membawa dampak yang baik kepada orang KTBK ini yang terutama bagi pemuda masa kini untuk menjadi pemimpin yang berkualitas. Visi dan misi menjadi bahan utama yang melaksanakan pemuridan dan digerakkan. Pemimpin yang mencari yang mengerjakan Panggilan Ilahi untuk memuridkan semua orang menjadi serupa dengan Yesus. Tanpa visi dan misi setiap pemimpin tidak akan bisa menjalani atau menghadapi tantangan akan dihadapi pada saat ini. ${ }^{4}$ Suatu proses KTBK untuk menjadi telada orang percaya adalah belajar Firma Tuhan yang bertujuan untuk bertumbuh menjadi serupa dengan Kristus yang membutuhkan bimbingan pengajaran Firman Tuhan.

Dampak pemuridan KTBK ini adalah bagi pemuda masa kini untuk kreatif dan inovatif dalam menghadapi berbagai tantangan pada masa ini dan bagaimana memecahkah masalah yang kita hadapin sebagai pemuda masa kini agar dapat menjadi pemimpin yang berkualitas harus bisa menjadi teladan yang baik bagi orang-orang di lingkungan sekitarnya, dan menunjukkan kasih kepada sesama, tentunya selalu menyampaikan Firman Tuhan dengan benar di sepanjang hidup terutama menjadikan Yesus Kristus sebagai pusat Pengajarannya.

\footnotetext{
${ }^{4}$ Daniel Fajar Panuntu and Eunike Paramita, "HUBUNGAN PEMBELAJARAN ALKITAB TERHADAP NILAI-NILAI (KELOMPOK TUMBUH BERSAMA KONTEKSTUAL)," Gamaliel: Teologi dan parktika 1, no.2 (2019) HIm. 140-115
} 


\section{KESIMPULAN}

Kesimpulan dari penelitian ini adalah agar pemuda masa kini dapat pembelajari Alkitab lebih mendalami dan pengembangan pemuridan kontekstual. Agar orang Kristen memiliki iman percaya kepada Kristus dan terus bertumbuh dalam Yesus Kristus, dengan pemuridan kontekstual ini akan membawa dampak yang baik bagi pemuda masa kini sehingga dapat menjadi pemimpin yang berkualitas Kristiani.

\section{SARAN}

Saran dari penilitian adalah agar mas kini dapan mengaplikasikan Pemuridan Kontekstual /KTBK dalam pribadi kita masing-masing.

Dalam mengerjakan Makalah ini saya memiliki banyak kekurang dengan itu saya mengharapkan untuk memberikan saran atau kritis bagi yang membacanya. Agar saya membuat penelitian kedepan bisa lebih baik lagi. 


\section{DAFTAR PUSTAKAAN}

Haryono, T dan Yuliati, Pemuridan Kontekstual : contextual bible group. (Surakarta, Yayasan Gamaliel, 2018).

Daniel Fajar Panuntun and Eunike Paramita, "HUBUNGAN PEMBELAJARAN ALKITAB TERHADAP NILAI-NILAI (KELOMPOK TUMBUH BERSAMA KONTEKSTUAL)," Gamaliel: Teologi dan parktika 1, no.2 (2019).

Hanyono, T dan Daniel Fajar Penuntun “ Andil Pemuridan Kontekstual Yesus Kepada Petrus Yakobus dan Yohanes Terhadap Keterbukaan Konseling Mahasiswa Pada Masa Kini.” Jurnal Gamaliel: Teologi Parktika vol 1, No,1 , 2019.

Badudu, S. J dan Sultan Muhammad Zain, Kamus Umum Bahasa Indonesia (Jakarta: Pustaka Sinar Harapan 1994),1028,s.v "Pemuda."

Zuck, B. Roy dan Warren S. Benson, Pedoman Lengkap Untuk Pelayanan Kaum Mudah Jilid 1 (Bandung: kalam Hidup, 1978), 